\title{
Inheritance Studies for Grain Yield and It's Attributes in Maize through Combining Ability Analysis
}

\author{
Naveed Kamal $^{1}$, Saeeda Khanum ${ }^{2}$, Muhammad Siddique ${ }^{2 *}$, Shahid Hussain ${ }^{3}$, Muhammad Farooq Ahmed ${ }^{4}$
}

${ }^{1}$ Maize Breeding Sub Station, Chharrapani, Murree, Pakistan

${ }^{2}$ Millets Research Station, Rawalpindi, Pakistan

${ }^{3}$ Maize and Millets Research Institute, Yusafwala -Sahiwal, Pakistan

${ }^{4}$ Sugarcane Breeding Sub Station, Murree, Pakistan

DOI: $10.36347 /$ sjavs.2020.v07i08.001

| Received: 23.07.2020 | Accepted: 31.07.2020 | Published: 05.08.2020

*Corresponding author: Muhammad Siddique

\section{Abstract}

Original Research Article

Present study was conducted during growing seasons 2018 and 2019 to explore the genetic makeup of five maize inbred lines: Elp-426, Elp-433, Elp-612, Elp-326 and Elp-780. Analysis of variance revealed highly significant differences for the quantitative traits like grain yield, cob length, rows per cob and number of grains per row. GCA was highly significant for cob length and rows per cob while significant for grain yield and number of grains per row. SCA was highly significant for grain yield, number of grains per row and rows per cob while it was significant for cob length. GCA / SCA ratio was greater than unity indicating that additive gene action had major contribution in the inheritance of these characters. Elp-433 was the best general combiner for grain yield, rows per cob and number of grains per row. Elp-426 and Elp-326 were good general combiners for grain yield and cob length. Elp-326 X Elp-780 was the best specific combination for grain yield, rows per cob and number of grains per row. Elp-426 X Elp-433 showed promise for all the metric traits studied. The crosses Elp-426 X Elp-780, Elp-433 X Elp-326, Elp-426 X Elp612, Elp-612 X Elp-326 and Elp-433 X Elp-612 also exhibited worth regarding grain yield and some of its attributes. These findings clearly indicated that the experimental material had sufficient variability which can successfully be used to boost yield by gene pyramiding through recurrent selection.

Keywords: CAA, Inheritance, maize.

Copyright @ 2020: This is an open-access article distributed under the terms of the Creative Commons Attribution license which permits unrestricted use, distribution, and reproduction in any medium for non-commercial use (NonCommercial, or CC-BY-NC) provided the original author and source are credited.

\section{INTRODUCTION}

It is challenging to feed the ever increasing human population. Although the yield of grain crops has been increased many folds over the past, still there is need to achieve sustained food production. Maize crop is one of the important cereals. It has highest yield potential [1]. Much of its potential has been explored during recent years by improving its genetics. It can be exploited further to increase its per acre yield. For this purpose a comprehensive knowledge of maize inheritance is crucial. Combining ability analysis is one of the commonly used tools to look in to the genetic behavior of the crop plants.

Both additive and non additive gene interactions have been reported by researchers like [2, 1, 3-10]. Such knowledge helps breeders in selecting genetically superior crop plants as well as the best breeding procedure. Present experiment was conducted to determine the genetic value of five maize inbred lines viz; Elp-426, Elp-433, Elp-612, Elp-326 and Elp-780.

\section{MATERIAL AND METHODS}

The experimental material was planted at Maize Breeding Sub Station Chharrapani (Murree) Pakistan. All possible crosses were made, harvested and were sown during next growing season on 25-03-2019. Data were recorded for grain yield, cob length, number of rows per cob and number of grains per row.

Analyses of variance were conducted for all the quantitative traits following [11] technique. All the parameters were highly significant (Table-1).

The analyses of general combining ability (GCA) and specific combining ability (SCA) were carried out using [12] technique, Method I model II.

\section{RESULTS AND DISCUSSION:}

Highly significant differences were observed for all the characteristics studied (Table-1). GCA mean squares were highly significant for cob length and rows per cob and significant for rest of the traits (Table-2). SCA mean squares were highly significant for grain 
yield, rows per cob and number of grains per row and significant for cob length only. Reciprocal mean squares were highly significant for all the characters under investigation. Elp-433 was proved the best general combiner for grain yield, rows per cob and grains per row. Elp-426 and Elp-326 were good general combiners for grain yield and cob length only (Table$3)$.

Elp-326 X Elp-780 was the best specific combination for grain yield, rows per cob and grains per row. Elp-426 X Elp-433 showed promise for all the parameters under study (Table-4). The crosses Elp-426
X Elp-780, Elp-433 X Elp-326, Elp-426 X Elp-612, Elp-612 X Elp-326 and Elp-433 X Elp-612 also exhibited worth regarding grain yield and some of its attributes.

Some superior reciprocals like Elp-780 X Elp433, Elp-780 X Elp-426, Elp-326 X Elp-426, Elp-326 X Elp-433, Elp-612 X Elp-426 and Elp-326 X Elp-612 were also noticed for grain yield and some of its attributes (Table-5). Both parents of the cross Elp-426X Elp-433 were good general combiners for grain yield and its related traits. Rest of the above crosses involved at least one good general combiner.

Table-1: Mean squares for grain yield, cob length, rows per cob and number of grains per row in $5 \times 5$ diallel cross in maize

\begin{tabular}{|l|l|l|l|l|l|}
\hline SOV & df & Grain Yield & Cob Length & Rows per cob & Number of grains per row \\
\hline Replications & 1 & 10981 & 2.0833 & 0.18750 & 2.521 \\
\hline Crosses & 24 & $3589331 * *$ & $16.9585 * *$ & $5.35343 * *$ & $112.102 * *$ \\
\hline Error & 24 & 50361 & 0.3299 & 0.09635 & 0.332 \\
\hline \multicolumn{7}{|l}{ *ignificant and $* *$ highly Significant at $5 \%$ and $1 \%$ level, respectively. }
\end{tabular}

Table-2: Combining ability mean squares for grain yield, cob length, rows per cob and grains per row in $5 \times 5$ diallel cross in maize

\begin{tabular}{|l|l|l|l|l|l|}
\hline SOV & Df & Grain Yield & Cob Length & Rows per cob & Grains per row \\
\hline GCA & 4 & $8393653.788 *$ & $71.99872449 * *$ & $53.33429 * *$ & $296.1079 *$ \\
\hline SCA & 10 & $1943930.71^{* *}$ & $6.73 *$ & $2.25 * *$ & $59.41 * *$ \\
\hline Reciprocals & 10 & $1499251.78 * *$ & $10.03 * *$ & $2.81 * *$ & $58.11^{* *}$ \\
\hline Error & 24 & 402890.33 & 2.64 & 0.77 & 2.66 \\
\hline
\end{tabular}

*significant and $* *$ highly Significant at $5 \%$ and $1 \%$ level, respectively.

Table-3: GCA effects for grain yield cob length, rows per cob and Number of grains per row in $5 \times 5$ diallel cross in maize

\begin{tabular}{|l|l|l|l|l|}
\hline Inbred Lines & Grain Yield & Cob Length & Rows per cob & Number of grains per row \\
\hline Elp-426 & 341.45 & 0.75 & 0.37 & 0.58 \\
\hline Elp-433 & 495.65 & 0.50 & 0.62 & 2.48 \\
\hline Elp-612 & -220.90 & -0.77 & -0.43 & 0.03 \\
\hline Elp-326 & 55.45 & 0.65 & 0.22 & 0.33 \\
\hline Elp-780 & -67.65 & -1.13 & -0.78 & -3.42 \\
\hline SE & 45.01 & 0.75 & 0.37 & 0.58 \\
\hline
\end{tabular}

Table-4: SCA effects for grain yield, cob length, rows per cob and number of grains per row in $5 \times 5$ diallel cross in maize

\begin{tabular}{|l|l|l|l|l|}
\hline Crosses & Grain Yield & Cob Length & Rows per cob & Number of grains per row \\
\hline Elp-426 x Elp-433 & 1053.65 & 2.40 & 1.03 & 4.17 \\
\hline Elp-426 x Elp-612 & 494.20 & -0.58 & -0.17 & 3.62 \\
\hline Elp-426 x Elp-326 & -377.40 & -2.38 & -0.57 & -3.68 \\
\hline Elp-426 x Elp-780 & 854.95 & 0.40 & 0.43 & 3.07 \\
\hline Elp-433 x Elp-612 & 31.00 & 0.80 & -0.17 & 0.22 \\
\hline Elp-433 x Elp-326 & 808.90 & 1.50 & 1.18 & 7.79 \\
\hline Elp-433 x Elp-780 & -599.25 & -1.85 & -0.82 & -4.96 \\
\hline Elp-612 x Elp-326 & 313.45 & -0.73 & 0.23 & 0.24 \\
\hline Elp-612 x Elp-780 & -365.95 & -1.95 & -0.77 & -4.51 \\
\hline Elp-326 x Elp-780 & 1068.45 & 1.00 & 1.58 & 5.82 \\
\hline
\end{tabular}


Table-5: Reciprocal Effects for grain yield, cob length, rows per cob and number of grains per row in 5x5 diallel cross in maize

\begin{tabular}{|l|l|l|l|l|}
\hline Crosses & Grain Yield & Cob Length & Rows per cob & Number of Grains per row \\
\hline Elp-433 x Elp-426 & -42.25 & 0.00 & 0.00 & 3.00 \\
\hline Elp-612 x Elp-426 & 204.75 & 0.25 & 0.25 & -1.00 \\
\hline Elp-612 x Elp-433 & -308.25 & 3.38 & 2.00 & 8.00 \\
\hline Elp-326 x Elp-426 & 1141.00 & 3.38 & 2.00 & 8.00 \\
\hline Elp-326 x Elp-433 & 835.50 & 1.88 & 0.00 & 1.50 \\
\hline Elp-326 x Elp-612 & 170.00 & 4.00 & 2.00 & 5.63 \\
\hline Elp-780 x Elp-426 & 1156.25 & 2.13 & 1.00 & 9.13 \\
\hline Elp-780 x Elp-433 & 1647.25 & -0.50 & 0.00 & -0.38 \\
\hline Elp-780 x Elp-612 & -692.50 & -1.50 & 0.00 & -3.88 \\
\hline Elp-780 x Elp-326 & -893.75 & -0.88 & -1.00 & -4.50 \\
\hline
\end{tabular}

Table-6: Variance Components for grain yield, cob length, rows per cob and number of grains per row in $5 \times 5$ diallel cross in maize

\begin{tabular}{|l|l|l|l|l|}
\hline Variance Components & Grain Yield & Cob Length & Rows per cob & Number of grains per row \\
\hline $\mathrm{Vg}$ & -3645.89 & -0.05 & 0.02 & -0.54 \\
\hline $\mathrm{Vs}$ & 917285.94 & 2.44 & 0.88 & 33.78 \\
\hline $\mathrm{Vr}$ & 548180.72 & 3.69 & 1.02 & 27.73 \\
\hline $\mathrm{Ve}$ & 402890.33 & 2.64 & 0.77 & 2.66 \\
\hline
\end{tabular}

\section{CONCLUSION}

Table 2 revealed that both additive and non additive gene actions had their role in the inheritance of grain yield and its related characters as GCA and SCA mean squares were significant or highly significant for all the traits studied. This fact was also supported by variance components. However larger SCA components for grain yield and grains per row advocated non additive gene action for the physiology of these characters. Present findings are in accordance with [1, 3-10].

\section{REFERENCES}

1. Haq MI, Ajmal S, Kamal N, Khanum S, Siddique M, Kiani MZ. Generation mean analysis for grain yield in maize. The Journal of Animal and Plant Sciences. 2013; 23(4):1146-1151.

2. Hussain M, Chughtai SR, Javed HI, Malik NH, Saleem A. Suitability of indigenous maize hybrids for spring planting in Pakistan. Asian J. Pl. Sci. 2006;5(2):296-9.

3. Moll R, Salhuana WS, Robinson HF. Heterosis and Genetic Diversity in Variety Crosses of Maize 1. Crop science. 1962; 2(3):197-8.

4. Mason L, Zuber MS. Diallel Analysis of Maize for Leaf Angle, Leaf Area, Yield, and Yield Components 1. Crop Science. 1976 Sep; 16(5):693-6.

5. Nienhuis J, Singh SP. Combining Ability Analyses and Relationships among Yield, Yield
Components, and Architectural Traits in Dry Bean 1. Crop Science. 1986 Jan; 26(1):21-7.

6. Malik SI, Malik HN, Minhas NM, Munir MU. General and specific combining ability studies in maize diallel crosses. International Journal of Agriculture \& Biology. 2004; 6(5):856-9.

7. Sharma S, Narwal MS, Kumar R, Dass S. Line $x$ tester analysis in maize (Zea mays L.). Forage Res. 2004; 30:28-30.

8. Muraya MM, Ndirangu CM, Omolo EO. Heterosis and combining ability in diallel crosses involving maize (Zea mays) S1 lines. Australian Journal of Experimental Agriculture. 2006 Apr 21; 46(3):387-94.

9. Seyoum A, Wegary D, Alamerew S. Combining ability of elite highland maize (Zea mays L.) inbred lines at Jimma Dedo, South West Ethiopia. Advances in Crop Science and Technology. 2016 Mar 1:1-9.

10. Gamble EE. Gene effects in corn (Zea mays L.): I. Separation and relative importance of gene effects for yield. Canadian Journal of plant science. 1962 Apr 1; 42(2):339-48.

11. Steel RGD, Torrie JH. Principles and procedures of statistics: A biological approach. $2^{\text {nd }}$ Edition, McGraw-Hill Inc., New York, 1980.

12. Griffing BR. Concept of general and specific combining ability in relation to diallel crossing systems. Australian journal of biological sciences. 1956; 9(4):463-93. 